\title{
First occurrence of Limnoperna fortunei (Dunker, 1857) in the Rio Tietê watershed (São Paulo State, Brazil)
}

\author{
Pareschi, DC. ${ }^{\mathrm{a}, \mathrm{b} *}$, Matsumura-Tundisi, . $^{\mathrm{b}}$, Medeiros, GR. ${ }^{\mathrm{b}}$, Luzia, AP. $^{\mathrm{a}, \mathrm{b}}$ and Tundisi, JG. ${ }^{\mathrm{b}}$ \\ aprograma de Pós-graduação em Ecologia e Recursos Naturais, Universidade Federal de São Carlos - UFSCar, \\ Rodovia Washington Luiz, Km 235, CEP 13565-905, São Carlos, SP, Brazil \\ 'Instituto Internacional de Ecologia - IIE, \\ Rua Bento Carlos, 750, Centro, CEP 13560-660, São Carlos, SP, Brazil \\ *e-mail: danipareschi@hotmail.com
}

Received March 26, 2008 - Accepted March 26, 2008 - Distributed November 30, 2008

(With 5 figures)

\begin{abstract}
This paper describes the recent expansion of the geographical distribution of Limnoperna fortunei (Dunker, 1857) in the Tietê River watershed, São Paulo State, Brazil. Estimations related to the velocity of invasion and its causes are presented. Ecological implications related to biodiversity and possible changes in the food chain are discussed.
\end{abstract}

Keywords: Limnoperna fortunei, invasors, benthic macroinvertebrates bentônicos, geografical distribution.

\section{Invasão de Limnoperna fortunei (Dunker, 1857) na bacia do rio Tietê (SP)}

\section{Resumo}

Este artigo descreve a recente expansão da distribuição geográfica de Limnoperna fortunei (Dunker, 1857) na bacia hidrográfica do rio Tietê, estado de São Paulo, Brasil. Foram apresentadas estimativas da velocidade de invasão destes organismos e sua via de entrada no rio Tietê. Foram discutidas as possíveis modificações na cadeia alimentar e as implicações ecológicas da invasão do mexilhão-dourado.

Palavras-chave: Limnoperna fortunei, invasores, macroinvertebrados bentônicos, distribuição geográfica.

\section{Introduction}

Limnoperna fortunei is a freshwater bivalve mussel that belongs to the Mytilidae family and it is native to China and Southeast Asia. It was first recorded in 1991 in South America at Bagliardi beach in the La Plata River Watershed (Pastorino et al., 1993), probably introduced through the ballast water of ships coming from China (Darrigran and Pastorino, 1995). From then on, Limnoperna fortunei has actively and passively dispersed through the Paraná and Uruguay River Basins.

This species has a great invasive potential due to its reproductive and opportunist characteristics (r-strategist), and reaches rapidly its sexual maturity and high reproductive rates, as well as having the capacity of establishing colonies in varied environmental conditions (euriothic) and high physiological tolerance (Darringran, 2002; Penchaszadeh, 2005). The absence of competition in the freshwater environment and the association of this species with human activities highly increase its dispersion capacity (Darringran, 2000). This species has a bissal attachment that it uses to attach itself to the surfaces of natural substrata (rocks, steams, aquatic vegetation, other organisms, etc) and of artificial substrata such as ship hulls, tabulations or other structures constructed by humans.

Therefore impacts caused by the golden mussel are being reported in natural and human environments. Pipeline blockages, turbine and water treatment station plan obstructions consume the most money among all of the economic impacts. The problems caused by $L$. fortunei in the systems constructed by humans in the Mercosul region are similar to those described for Dreissena polymorpha, a species that originally appears in the Caspian Sea in North America, generating an annual cost of U\$ 5 billions to clean tubulations that have been taken over by the invasor species (Khalanski, 1997; Darrigran and Damborenea, 2005). Impacts on natural populations can be irreversible causing fast transformations in benthic macroinvertebrate communities. Darrigran et al. (1998), studying the Bagliardi balneary in Argentina, in three years detected the disappearance of native species such as the gastropod Chilina fluminea and Gundlachia cocentrica and the appearance 
of Oligochaeta, Hirudinea's species among others, probably in uenced by the modification of the habitat caused by the golden mussel's settlement on rocky beaches, that a couple of years before, had been inhabited by native species (Darrigran, 2002). The golden mussel can attach to native speciess and inhibit their development, as Anodontites trapesialis bivalve and Aegla platensis crab (Darrigran et al., 2000). Due to its high biomass and density, Limnoperna fortunei can cause alterations in the food chain, serving as food for native fishes (Darrigran and Damborenea, 2005)

Actions to prevent and control the expansion and growth of the golden mussel have become extremely important because of ecological and economical damage. In Brazil, the Environment Ministry has been encouraging research related to exotic species through PROBio and is establishing priority actions to be developed and supported by the Environment Ministry for the period from 2008 until 2011, with strategy recommendations, action mechanisms to be used on prevention, eradication, mitigation and control of exotic invading species in the affected region and its impacts.

Darringran and Damborenea (2005) highlight the main steps to guide golden mussel control: a) scientific knowledge of this species, focused on its control; b) development of sustainable preventive and controlling methods; c) diffusion of the necessary information to restrict the expansion of the golden mussel to new regions.

The aim of this paper is to inform and alert about the new occurrence of the golden mussel in the medium Tietê region (São Paulo State, Brazil) during the development of the CT-Hidro/FINEP project. The displacement velocity through Paraná and Tietê rivers was also evaluated.

\section{Material and Methods}

Samplings were taken in two reservoirs of the medium Tietê River (São Paulo State, Brazil): UHE Ibitinga and UHE Bariri in July 2005 and February 2006 (Figure 1), during the expedition for the development of a doctoral thesis in the Tietê/Jacaré hydrographic basin. The main goal of this study was to evaluate the benthic macroinvertebrate community such as water quality indicators and its relation to the activities of the hydrographic basin. Five sites were sampled in each reservoir as showed on Figure 2 and Table 1.

Benthic macroinvertebrates were collected using an Ekman-Birge dredge measuring $3,375 \mathrm{~cm}^{3}$ $(15 \times 15 \times 15 \mathrm{~cm})$ and an artificial substrata measuring $2080 \mathrm{~cm}^{3}(26 \mathrm{~cm} \times 16 \mathrm{~cm} \times 5 \mathrm{~cm})$, made with polyethylene pead web and expanded argil measuring $2080 \mathrm{~cm}^{3}$ $(26 \mathrm{~cm} \times 16 \mathrm{~cm} \times 5 \mathrm{~cm})$ as shown in Figure 3 . The dredge samples were collected in littoral and profundal zones in five sites at each reservoir. The artificial substrata were left in the environment for one month for colonization in five sites of each reservoir. After being removed from the environment, the pieces of artificial substrata were washed through a net of $210 \mu \mathrm{m}$ mesh size and the samples were preserved in $70 \%$ alcohol. The organisms were removed onto a board under a light source and identified with a stereoscopic microscope. The direct counting of the number of individuals was made by the site and sampling methods.

Calculus of the population density were made using the square surface of the sampler, $0.0416 \mathrm{~m}^{2}$ for the artificial substrata and $0.0225 \mathrm{~m}^{2}$ for the Eckman dredge. The number of individuals registered by class of size (body length) considering the two reservoirs and sampling period was determinate. The biometric of shells was obtained using a pachymeter.

Water variables (temperature, $\mathrm{pH}$, dissolved oxygen, turbidity, electric conductivity, oxide-reduction potential and total dissolved solids) were obtained in situ with a multi sensor Horiba U22.

Calculus of the distance $(\mathrm{km})$ explored by the golden mussel from Itaipu to Bariri reservoir was based on satellite images obtained on Google earth (free software, 2007 version - earth.google.com/download-earth.html - 19k). As a baseline for geographical localization and dates of Limnoperma fortunei occurrence, Mansur et al. (2004), Avelar et al. (2004) and Von Rukert et al. (2004) were used.

\section{Results and Discussion}

Figure 4 shows the routes explored from the Paraná to Tietê rivers by the golden mussel, with records of date and time.

Limnoperna fortunei was first recorded in South America in 1991, at Bagliard beach, in the Rio de La Plata Watershed (Argentina) (Pastorino et al, 1993). In 1993, it was registered in La Plata River from Punta Piedras to Punta Lara (Buenos Aires). In 1996 the golden mussel was already found at several sites along Paraná River, in Argentine territory (Zárate, San Pedro, Rosário, Santa Fé) and in Paraguay (Darringran, 2000; Darringran and Ezcurra de Drago, 2000a,b). In 1998 this species was first recorded in Guaiba Lake, Rio Grande do Sul State, Brazil. From 1998 on, Limnoperna fortunei was registered going up Paraguay River and was found in Corumbá (Mato Grosso do Sul State, Brazil) in April, 2000. One year later, it was also registered in high Paraná River, in Itaipú Reservoir and in Uruguay River (Mansur et al., 2004a). In November 2002, Avelar et al. (2004) found the golden mussel in Paraná River, near Rosana city. Von Rukert et al. (2004) recorded Limnoperna fortunei in Jupiá Reservoir and upstream from the Hydroelectric Mill of Ilha Solteira in 2004. In studies by França (2006) and Suriani (2006) on benthic macroinvertebrates of the low and medium Tietê River, respectively in 2002 and 2003, the presence of the golden mussel in the sampled reservoirs was not mentioned. This indicates that the golden mussel invasion in Tietê River occurred only after 2004. In 2005, the presence of Limnoperna fortunei 

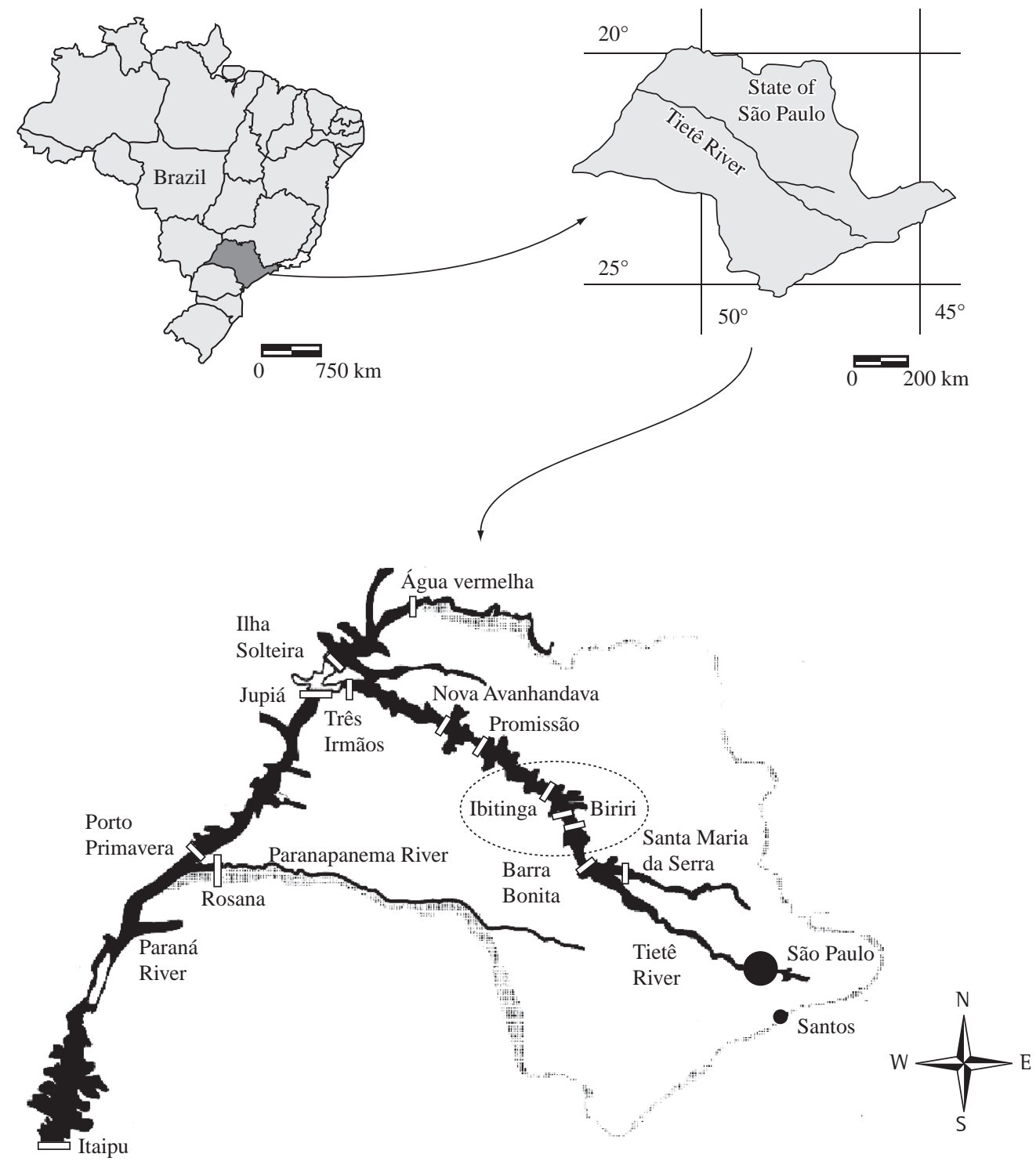

Figure 1. Location of studied reservoirs: UHE Ibitinga and UHE Bariri, Tietê River, São Paulo State, Brazil. Source: Barbosa et al. (1999).

Table 1. Description of sampled sites and its geographic locations.

\begin{tabular}{cll}
\hline Estation & \multicolumn{1}{c}{ Description } & \multicolumn{1}{c}{ Geographical location } \\
\hline Ibi 1 & Ibitinga reservoir, next the dam & $21^{\circ} 45^{\prime} 30^{\prime \prime} \mathrm{S}$ and $48^{\circ} 58^{\prime} 57^{\prime \prime} \mathrm{O}$ \\
Ibi 2 & Ibitinga reservoir, Jacaré Guaçú river & $21^{\circ} 49^{\prime} 24^{\prime \prime} \mathrm{S}$ and $48^{\circ} 54^{\prime} 22^{\prime \prime} \mathrm{O}$ \\
Ibi 3 & Ibitinga reservoir, between Jacaré Guaçú and Jacaré Pepira rivers & $21^{\circ} 52^{\prime} 28^{\prime \prime} \mathrm{S}$ and $48^{\circ} 54^{\prime} 10^{\prime \prime} \mathrm{O}$ \\
Ibi 4 & Ibitinga reservoir, Jacaré Pepira river & $21^{\circ} 53^{\prime} 50^{\prime \prime} \mathrm{S}$ and $48^{\circ} 50^{\prime} 04^{\prime \prime} \mathrm{O}$ \\
Ibi 5 & Ibitinga reservoir, amount Jacaré Pepira river & $21^{\circ} 55^{\prime} 33^{\prime \prime} \mathrm{S}$ and $48^{\circ} 54^{\prime} 27^{\prime \prime} \mathrm{O}$ \\
Bar 1 & Bariri reservoir, next the dam & $22^{\circ} 09^{\prime} 44^{\prime \prime} \mathrm{S}$ and $48^{\circ} 44^{\prime} 36^{\prime \prime} \mathrm{O}$ \\
Bar 2 & Bariri reservoir, Jaú river & $22^{\circ} 11^{\prime} 26^{\prime \prime} \mathrm{S}$ and $48^{\circ} 41^{\prime} 25^{\prime \prime} \mathrm{O}$ \\
Bar 3 & Bariri reservoir, between Bauru and Jaú rivers & $22^{\circ} 12^{\prime} 40^{\prime \prime} \mathrm{S}$ and $48^{\circ} 44^{\prime} 11^{\prime \prime} \mathrm{O}$ \\
Bar 4 & Bariri reservoir, Bauru river & $22^{\circ} 14^{\prime} 49^{\prime \prime} \mathrm{S}$ and $48^{\circ} 47^{\prime} 48^{\prime \prime} \mathrm{O}$ \\
Bar 5 & Bariri reservoir, amount Bauru river & $22^{\circ} 15^{\prime} 23^{\prime \prime} \mathrm{S}$ and $48^{\circ} 45^{\prime} 41^{\prime \prime} \mathrm{O}$ \\
\hline
\end{tabular}



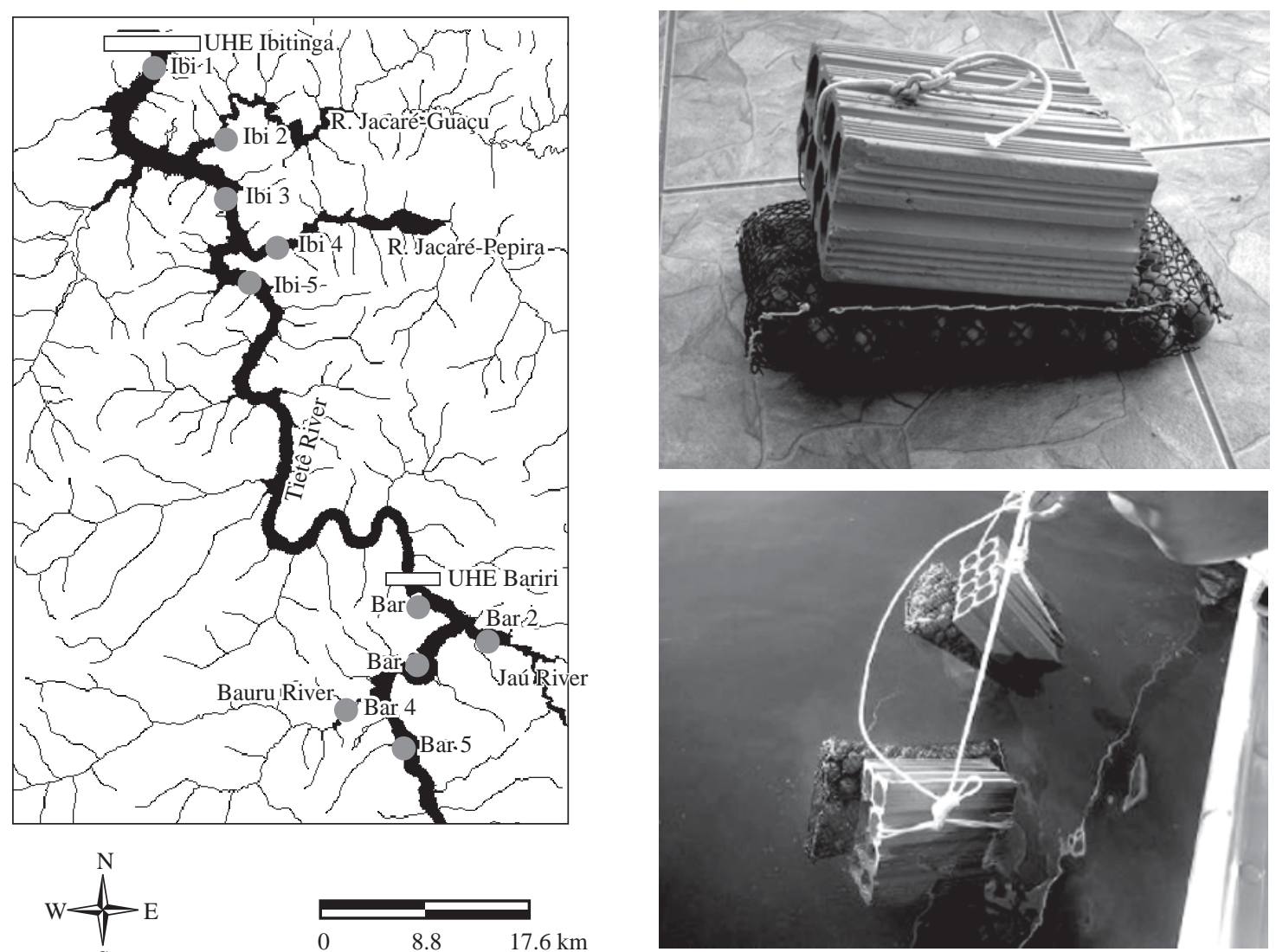

Figure 3. Artificial substrata used in this study.

Figure 2. Hydrographic map of UHE Ibitinga and UHE Bariri reservoirs and main tributary rivers with the indication of sampled sites.

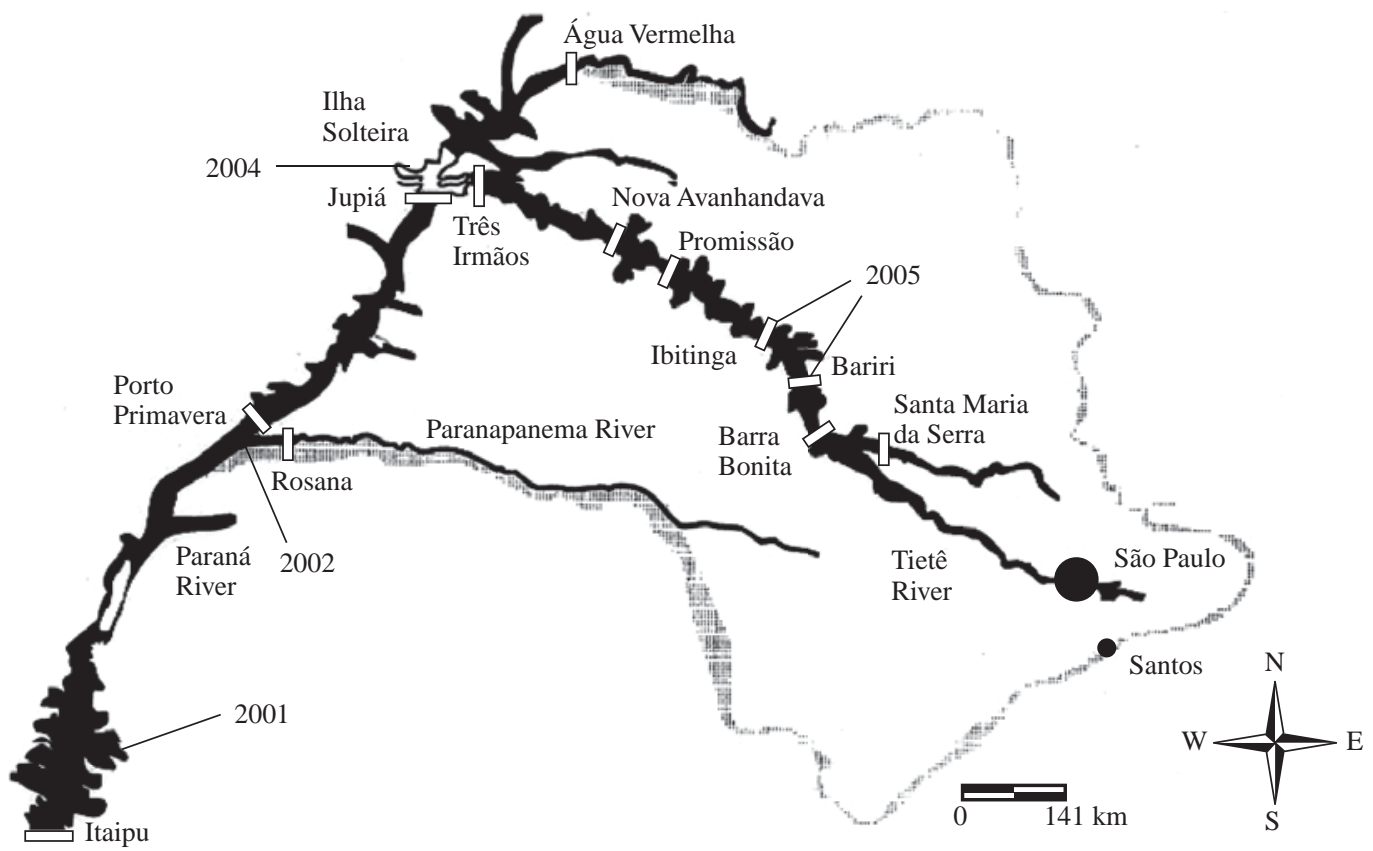

Figure 4. Map of the State of São Paulo showing the main rivers (Paraná, Tietê and Paranapanema), and the occurrence dates of Limnoperma fortunei at the indicated sites. Modified from Barbosa et al. (1999). 
in Ibitinga and Bariri Reservoirs (medium Tietê River) was registered.

Darringran (2000) and Darringran and Ezcurra de Drago $(2000 \mathrm{a}$; b) estimated an upstream movement of the golden mussel of $240 \mathrm{~km}$ per year. In this research a total movement of 1,057 km was calculated from Itaipu reservoir, Paraná River, to Bariri Reservoir, Tietê River, in a four-year period which means an average of $264 \mathrm{~km}$ upstream movement by Limnoperna fortunei.

It was registered a total of 459 individuals at ten sample sites on tow reservoirs, considering the two periods of sampling. The results are shown in Table 2 . It is noticed that most of the organisms were registered as occurring in the Ibitinga reservoir, specially on artificial substrata from July 2005 (winter and dry season). In the Bariri reservoir, only a low density of organisms were found on artificial substrata. No Limnoperma fortunei individuals were found in the reservoir profundal zone, showing that its distribution occurs mainly in shallow regions of the reservoir's margins, the deepness of which varies from 0.3 to $5 \mathrm{~m}$. The deepness of the profundal zone sampled sites varied from 7 to $22 \mathrm{~m}$.
In February 2006 (summer and rainy season), Limnoperma fortunei occurred only at two sites, in the Ibitinga reservoir (Ibi 4, with 124 individuals) and at the site Bar 5 of Bariri reservoir, with one individual. It's important to highlight that there was loss of artificial substrata in February 2006, making it impossible to determine whether the summer and rainy season in uenced the distribution and occurrence of Limnoperma fortunei. Long term research on the alluvial plain of high Paraná river has been registering Limnoperma fortunei during all seasons of the year and in greater abundance in channels with currents (Takeda et al., 2004).

The density of organisms in $\mathrm{m}^{2}$ at each sampled site of the reservoirs is shown in Table 3. Density variations from 8 to 6.267 ind. $\mathrm{m}^{-2}$ were observed. Darrigran and Damborenea (2005) have been registering densities from 5 ind. $\mathrm{m}^{-2}$ to 150.000 ind. $\mathrm{m}^{-2}$ at Bagliardi beach in Argentina, drawing attention to the big seasonal uctuations in population density of Limnoperma fortunei and the importance of continuous temporal registers for the investigation of environmental factors that in uence its development.

Table 2. Total number of Limnoperma fortunei by sampled site and sampler in each period for the Ibitinga reservoirs.

\begin{tabular}{|c|c|c|c|c|c|c|}
\hline \multirow[t]{3}{*}{ Estation } & \multicolumn{6}{|c|}{ Total number of individuals } \\
\hline & \multicolumn{2}{|c|}{ Artificial substrate } & \multicolumn{2}{|c|}{ Dredger margin zone } & \multicolumn{2}{|c|}{ Dredger profundal zone } \\
\hline & July/05 & Feb./06 & July/05 & Feb./06 & July/05 & Feb./06 \\
\hline Ibi 1 & 27 & 0 & 0 & 0 & 0 & 0 \\
\hline Ibi 2 & 4 & - & 0 & 0 & 0 & 0 \\
\hline Ibi 3 & 68 & - & 141 & 0 & 0 & 0 \\
\hline Ibi 4 & 4 & 124 & 0 & 0 & 0 & 0 \\
\hline Ibi 5 & 88 & - & 0 & 0 & 0 & 0 \\
\hline Bar 1 & 0 & - & 0 & 0 & 0 & 0 \\
\hline Bar 2 & 1 & 0 & 0 & 0 & 0 & 0 \\
\hline Bar 3 & 0 & - & 0 & 0 & 0 & 0 \\
\hline Bar 4 & - & 0 & 0 & 0 & 0 & 0 \\
\hline Bar 5 & 1 & 1 & 0 & 0 & 0 & 0 \\
\hline
\end{tabular}

Table 3. Density (ind. $\mathrm{m}^{-2}$ ) of Limnoperma fortunei by sampled site and sampler in each period for the Ibitinga reservoirs.

\begin{tabular}{|c|c|c|c|c|c|c|}
\hline \multirow[t]{3}{*}{ Estation } & \multicolumn{6}{|c|}{ Density (ind.m ${ }^{-2}$ ) } \\
\hline & \multicolumn{2}{|c|}{ Artificial substrate } & \multicolumn{2}{|c|}{ Dredger margin zone } & \multicolumn{2}{|c|}{ Dredger profundal zone } \\
\hline & July/05 & Feb./06 & July/05 & Feb./06 & July/05 & Feb./06 \\
\hline Ibi 1 & 216 & 0 & 0 & 0 & 0 & 0 \\
\hline Ibi 2 & 32 & - & 0 & 0 & 0 & 0 \\
\hline Ibi 3 & 545 & - & 6267 & 0 & 0 & 0 \\
\hline Ibi 4 & 32 & 994 & 0 & 0 & 0 & 0 \\
\hline Ibi 5 & 705 & - & 0 & 0 & 0 & 0 \\
\hline Bar 1 & 0 & - & 0 & 0 & 0 & 0 \\
\hline Bar 2 & 8 & 0 & 0 & 0 & 0 & 0 \\
\hline Bar 3 & 0 & - & 0 & 0 & 0 & 0 \\
\hline Bar 4 & - & 0 & 0 & 0 & 0 & 0 \\
\hline Bar 5 & 12 & 12 & 0 & 0 & 0 & 0 \\
\hline
\end{tabular}


The biometry of organisms showed individuals of four size categories (up to $5 \mathrm{~mm}$; from 6 to $10 \mathrm{~mm}$; from 11 to $15 \mathrm{~mm}$; from 16 to $20 \mathrm{~mm}$ ) is shown in Figure 5 and Table 4 . Shell length varied from 3 to $20 \mathrm{~mm}$; height (greatest antero-posterior distance) varied from 2 to $10 \mathrm{~mm}$ and dorso-ventral width varied from 1 to $7 \mathrm{~mm}$. The number of individuals by class of size is shown in Table 4.

Most registered organisms showed variable widths from 10 to $15 \mathrm{~mm}$. Boltovskoy and Cataldo (1999) observed that during the first year of growth, shell size increased $20 \mathrm{~mm}$ in length; in the second year, shells measured $30 \mathrm{~mm}$ in length, and the theoretical maximum length is $35 \mathrm{~mm}$. According to Darringran (2002) the maximum shell length recorded in The Prata Basin is of approximately $45 \mathrm{~mm}$. According to the same author, the maximum length of shells from individuals found in Prata basin is around $45 \mathrm{~mm}$. According to Morton (1982), the maximum shell length varies from 30 to $40 \mathrm{~mm}$.

The maximum shell length registered in this research was of $20 \mathrm{~mm}$, and $85 \%$ of the collected organisms presented total length of $10 \mathrm{~mm}$. A high density of Limnoperma fortunei larvae on plankton samples was also registered. Based on these data it can be inferred

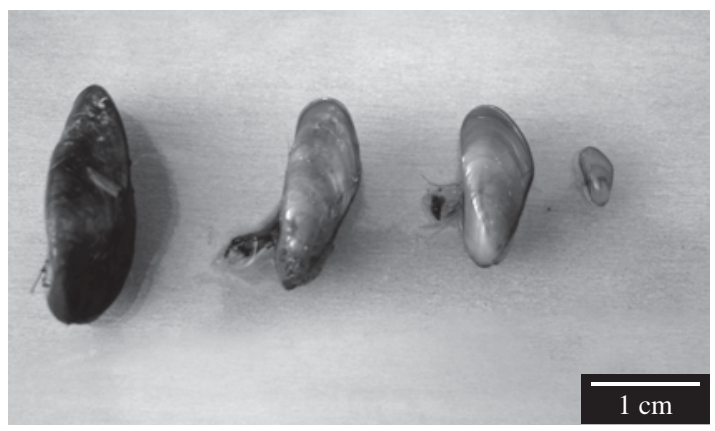

Figure 5. Specimens Limnoperma fortunei found in the Bariri and Ibitinga reservoirs. that populations registered in both Tietê River reservoirs are young, probably in their first year of life and in the colonization process.

Physical and chemical water characteristics of several sites in Bariri and Ibitinga Reservoirs, where specimens of Limnoperna fortune $i$ were found, are shown in Table 5. Limnoperma fortune $i$ was registered in $\mathrm{pH}$ ranging from 7.27 to 9.96 and 4.66-16.69 $\mathrm{Ca}^{++}$. Darrigran (2002) registered L. fortunei in areas where the $\mathrm{pH}$ varied from 6.2 to 7.4 and $3.96 \mathrm{mg} . \mathrm{L}^{-1}$ de $\mathrm{Ca}^{++}$. These results show that Limnoperna fortunei can inhabit a great range of different environmental conditions and its invasive potential.

Some other species of invading mollusk, such as the gastropod Melanoides tuberculata and the bivalve Corbicula fluminea, originally from the Asiatic southeast and introduced into Brazil in the 60's, were found in the Ibitinga and Bariri reservoirs in the present study. Despite the lack of previous systematic studies carried out in the medium and low Tietê, França et al. (2007) and Suriani et al. (2007) reported the greatest abundance of Melanoides tuberculata when compared to the gastropod Aylacostoma tenuilabris native to this region's reservoirs. Preliminary research from Fernandez et al. (2003) indicates that the same fact has been occurring in the Tocatins river, where the population of A. tenuilabris is being substituted by $M$. tuberculata.

The decrease or even disappearance of native species such as glabrata and Pomacea lineate caused by the establishment of $M$. tuberculata and $C$. fluminea have been reported by several researchers studying different regions of the country (Giovanelli et al., 2001; Guimarães et al., 2001; Fernandez et al., 2003; Mansur et al., 2004b; Takeda et al., 2004).

Amongst all the invading mollusks, L. fortunei seems to be the most aggressive, with wide environmental tolerance and capacity to occupy different niches, given specially by the presence of a byssal structure, which is used to fix the organism to several substrata. Takeda et al.

Table 4. Number of individuals and percentage of Limnoperma fortunei by class of size (length of shell) registered in July/05 and Feb./06 in the Bariri and Ibitinga reservoirs.

\begin{tabular}{lcccc}
\hline & \multicolumn{4}{c}{ Class size } \\
\cline { 2 - 5 } & until $\mathbf{5 ~} \mathbf{~ m m}$ & $\mathbf{6}$ to $\mathbf{1 0} \mathbf{~ m m}$ & $\mathbf{1 1}$ to $\mathbf{1 5} \mathbf{~ m m}$ & $\mathbf{1 6}$ to 20 $\mathbf{~ m m ~}$ \\
\hline Number of individuals & 247 & 141 & 66 & 5 \\
Percent & $54 \%$ & $31 \%$ & $14 \%$ & $1 \%$ \\
\hline
\end{tabular}

Table 5. Variation of water's physical and chemical characteristics in the five sampled sites where Limnoperna fortunei was found. The numbers presented correspond to maximums and minimums measured during the sampling period (July/05 and Feb./06).

\begin{tabular}{lccccccc}
\hline $\begin{array}{l}\text { Parameters } \\
\text { of water }\end{array}$ & $\mathbf{p H}$ & $\begin{array}{c}\text { Conductivity } \\
\left(\mu \mathbf{S . c m}^{-1}\right)\end{array}$ & $\begin{array}{c}\text { Turbidity } \\
(\mathbf{N T U})\end{array}$ & $\begin{array}{c}\text { Oxygen } \\
\left(\mathbf{m g . L ^ { - 1 }}\right)\end{array}$ & Temperature $\left({ }^{\circ} \mathbf{C}\right)$ & TDS $\left(\mathbf{g . L} \mathbf{L}^{-1}\right)$ & ORP $(\mathbf{m V})$ \\
\hline $\begin{array}{l}\text { Minimum and } \\
\text { maximum } \\
\text { values }\end{array}$ & $7.27-9.96$ & $44-232$ & $3-62.4$ & $6.78-10$ & $19.9-33.1$ & $0.01-0.18$ & $133-335$ \\
\hline
\end{tabular}


(2004) found the highest density of L. fortunei compared to $C$. fluminea at the high Paraná river. This fact was also observed in several sites of Bariri and Ibitnga reservoirs during the present research.

The golden mussel has high filtration rates and by reaching dense populations can affect aquatic communities and nutrients cycling. Their feeding consists of algae and other oating particles, and when it is fed with toxic Cyanobacteria, it can accumulate and transfer cyanotoxins throughout the food web. It is verified that $L$. fortune $i$ serve as food to some native fish species (Von-Ruckert et al., 2004; Takeda et al., 2004). The high rates of filtration, the competition with native filtrating organisms and the decreasing of the phytoplakncton biomass and turbidity could lead to an increase of zooplankton biomass (Darrigran and Pastorino, 1995; Ricciardi, 1998; Darrigran e Ezcurra de Drago, 2000).

Modifications in the macro invertebrate communities caused by the invasion of $L$. fortunei have been shown in the Plata Basin, Argentina, by Darrigran (2002), among other researchers. The impacts of macrofouling have been described in water systems and electrical turbines in countries of South America, where the golden mussel has already invaded (Darrigran and Damborenea, 2005).

The golden mussel has been establishing itself in the low and medium Tiete River, and due to the velocity of its expansion, it can probably already be registered in the high Tiete River and in the Paranapanema River, where studies should be carried out in order to verify its occurrence. It is necessary to prevent and control the expansion of these populations; if not, ecologic alterations can occur, such as native community alterations and economic loss, as described in the literature (macrofouling).

Acknowledgements - The authors thank all colleagues at the IIE (International Institute of Ecology) for the support in the field and laboratory work. We also thank Carolina Cunha Andrade and Natalia Andriocioli Periotto for the help with the translation. This study was financed with resources from FINEP/ CT-Hidro (reference no. 3504/04 - Conv.01.04.0999.00) and by a doctoral scholarship from CNPQ/CT-Hidro (process no. 142508/2004-7)

\section{References}

AVELAR, WEP., MARTINS, SL. and VIANNA, MP., 2004. A new occurrence of Limnoperna fortunei (Dunker 1856) (Bivalvia, Mytilidae) in the State of São Paulo, Brazil. Braz. J. Biol. $=$ Rev. Bras. Biol., vol. 64, no. 4, p. 739-742.

BARBOSA, FAR., PADISÁK, J., ESPÍNDOLA, ELG., BORICS, G. and ROCHA, O., 1999. The Cascading Reservoir Continuum Concept (CRCC) and its Application to the River Tietê-basin, São Paulo State, Brazil. In TUNDISI, JG. and STRAŠKRABA, M. (Eds.). Theoretical Reservoir Ecology and its Applications. São Carlos, Rio de Janeiro, Leiden, Holanda: IIE, BAS/Backhuys Publishers. p. 425-437.

DARRIGRAN, G. and DAMBORENEA, MC., 2005. El mejillón dorado Limnoperna fortunei (Dunker, 1857) en la Cuenca del Plata. In Penchaszadeh, PE. (Coord.). Invasores:
Invertebrados exóticos en el Río de la Plata y región marina aledaña. Buenos Aires: Eudeba. p. 39-102.

DARRIGRAN, G. and EZCURRA De DRAGO, I., 2000. Invasion of Limnoperna fortunei (Dunker, 1857) (Bivalvia: Mytilidae) in America. Nautilus, vol. 2, p. 69-74.

DARRIGAN, G., MARTIN, SM., GULLO, B. and ARMENDARIZ, L. 1998. Microinvertebrates associated with Limnoperna fortunei (Dunker, 1957) (BIVALVIA, MYTILIDAE) In Rio de la Plata, Argentina. Hydrobiologia, vol. 367 , p. 223-230.

DARRIGRAN, G. and PASTORINO, G., 1995. The recent introduction of a freshwater asiatic bivalve, Limnoperna fortunei (Mytilidae) into South America. The Veliger, vol. 38, no. 2, p. 171-175.

DARRIGRAN, G., 2000. Invasive Freshwater bivalves of the Neotropical Region. Dreissena, vol. II, no. 2, p. 7-13.

-, 2002. Potencial impact of filter-feeding invaders on temperate inland freshwater environments. Biol. Inv., vol. 4, p. 145-156.

DARRIGRAN, G., PENCHASZADEH, P. and. DAMBORENEA, MC., 2000. An invasion tale: Limnoperna fortunei (Dunker, 1857) (Mytilidae) in the Neotropics. In Claudi, R. (Ed.). Proceedings $10^{\text {th }}$ International Aquatic Nuisance Speciess and Zebra-Mussels Conference, Toronto, Canada.

FERNANDEZ, MA., THIENGO, SC. and BOAVENTURA, MF., 2001. Gastrópodes Límnicos do Campus de Manguinhos. Rev.Soc.Bras.Med. Trop, vol. 3, no. 34, p. 279-282.

FERNANDEZ, MA., THIENGO, SC. and SIMONE, LR., 2003. Distribution of the introduced freshwater snail Melanoides tuberculatus (Gastropoda: Thiaridae) in Brazil. The Nautilus, vol. 117, no. 3, p. 78-82.

FRANÇA, RS., 2006. A comunidade de invertebrados bentônicos nos reservatórios de Promissão, Nova Avanhandava e Três Irmãos (Baixo rio Tietê - SP). São Carlos, SP: Universidade Federal de São Carlos. [Dissertação de Mestrado].

FRANÇA, RS., SURIANI, AL. and ROCHA, O., 2007. Composição de espécies de moluscos bentônicos nos reservatórios baixo rio Tietê (São Paulo, Brasil) com uma avaliação do impacto causado pelas espécies exóticas invasoras. Rev. Bras. Zool., vol. 24, no. 1, p. 41-51.

GIOVANELLI, A., SILVA, CLPA., MEDEIROS, L. and VASCONCELOS, MC., 2001. The molluscicidal activity of the latex of Euphorbia splendens var. hislopii on Melanoides tuberculata (Thiaridae), a snail associated with habitats of Biomphalaria glabrata (Planorbidae). Mem. Inst.Oswaldo Cruz, vol. 96, no. 1, p. 123-125.

GUIMARÃES, CT., SOUZA, CP. and SOARES, DM., 2001. Possible competitive displacement of planorbids by Melanoides tuberculata in Minas Gerais, Brazil. Mem. Inst. Oswaldo Cruz, vol. 96, supl., p. 173-176.

KHALANSKI, M., 1997. Industrial and ecological consequences of the introduction of new speciess in continental aquatic ecosystems: the zebra mussel and other invasive speciess. Bull. Fr. Peche Piscic., no. 344-345, p. 385-404.

MANSUR, MCD., CALLIL, CT., CARDOSO, FR. and IBARRA, JAA., 2004b. Uma retrospectiva e mapeamento da invasão de espécies de Corbicula (Mollusca, Bivalvia, Veneroida, Corbiculidae) oriundas do sudeste asiático, na América do Sul, 
Brasil. In SILVA, JSV. and SOUZA, RCCL. (Orgs.). Água de Lastro e Bioinvasão. Rio de Janeiro: Interciência. p. 39-58.

MANSUR, MCD., QUEVEDO, CB., SANTOS, CP. and CALLIL, CT., 2004a. Prováveis vias de introdução de Limnoperna fortunei (Dunker, 1857) (Mollusca, Bivalvia, Mytilidae) na Bacia da Laguna dos Patos, Rio Grande do Sul e novos registros de invasão no Brasil pelas bacias do Paraná e Paraguai. In SILVA, JSV. and SOUZA, RCCL. (Orgs.). Água de Lastro e Bioinvasão. Rio de Janeiro: Interciência. p. 33-38.

MORTON, BS., 1982. The reproductive cycle in Limnoperna fortunei (Dunker 1857) (Bivalvia: Mytilidae) in Plover Cove reservoir, Hong Kong. Malacologia, vol. 16, p. 165-182.

PASTORINO, G., DARRIGRAN, G., MARTÍN, S. and LUNASCHI, L., 1993. Limnoperna fortunei (Dunker, 1857) (Mytilidae), Nuevo bivalvo invasor en aguas del Rio de La Plata. Neotropica, vol. 39, no. 101-102, p. 34.

PENCHASZADEH,PE., 2005.Invasores.InPENCHASZADEH, PE. (Coord.). Invasores: Invertebrados exóticos en el Río de la Plata y región marina aledaña. Buenos Aires: Eudeba. p. 21-37.

RICCIARDI, A., 1998. Global range expansion of the Asian mussel Limnoperna fortunei (Mytilidae): Another fouling threat to freshwater systems. Biofouling, vol. 13, no. 2, p. 97-100.
SURIANI, AL., 2006. A estrutura da comunidade de macroinvertebrados bentônicos em três represas do médio rio Tietê $(S P)$, com ênfase nas espécies exóticas Melanoides tuberculata (Gastropoda, Thiaridae) e Corbicula fluminea (Bivalvia, Corbiculidae). São Carlos: Universidade Federal de São Carlos. [Dissertação de Mestrado].

SURIANI, AL., FRANÇA, RS. and ROCHA, O., 2007. A malacofauna bentônica das represas do médio rio Tietê (São Paulo, Brasil) e uma avaliação ecológica das espécies exóticas invasoras, Melanoides tuberculata (Müller) e Corbicula fluminea (Müller). Rev. Bras.Zool., vol. 24, no. 1, p. 21-32.

TAKEDA, AM., FUJITA, DS. and FONTES, HM., 2004. Perspectives on exotic bivalves proliferation in the Upper Paraná River Floodplain. In AGOSTINHO, AA., RODRIGUES, L., GOMES, LC., MAGELA, TS. and MIRANDA, LE. (Eds.). Structure and functioning of the Paraná River and its floodplain. Maringá: EDUEM, p. 97-100.

VON RUCKERT, G., CAMPOS, MCS. and ROLLA, ME., 2004. Alimentação de Limnoperna fortunei (Dunker 1857): taxas de filtração com ênfase ao uso de Cyanobacteria. Acta Sci. Biol. Sci., vol. 26, no. 4, p. 421-429. 